\title{
Effect of Emotional Intelligence and Trust on Organizational Commitment among Nursing staff
}

\author{
Hassnaa Fathi Zedan', Samah Mohamed Abdallah ${ }^{2}$ \& Karima Hosny Abdel Hafez \\ ${ }^{1 .}$ Nursing supervisor, Directorate of Health, Assiut ,Egypt. \\ 2. Professor of Nursing Administration, Faculty of Nursing, Assiut University, Egypt. \\ ${ }^{3 .}$ Assistant professor of Nursing Administration, Faculty of Nursing, Assiut University, Egypt.
}

\begin{abstract}
Back ground: People with high level of emotional intelligence become more mature enough in managing their emotion and capable of dealing with stress, while individual with low emotional intelligence will have too much stress this affected to level of trust and level of commitment, they cannot manage their emotion, loss of control unable to facing circumstance and deal effectively with other, individual with high level of emotional stability become more interested in their work environment and had high level of loyalty and commitment to their work. because .This study aim to determine Effect of Emotional Intelligence and Trust on Organizational Commitment among Nursing staff . Research design: A Descriptive cross-section design was used. Sitting: The study was conducted at three hospitals ( main Assuit University Hospital, Health Insurance Hospital, General Assuit Hospital) A study subjects consists of (575) nursing staff which classified to (nurse mangers 81 and staff nurses 494). Study tools : Consists of four tools: personal characteristics, Emotional intelligence , trust and organization commitment Results: Displayed that there was positive correlation between emotional intelligence and trust( $\mathrm{r}$-value $=0.225)$ and positive correlation between trust and organizational commitment ( $r$-value $=0.250)$. Conclusion: The finding of the current study confirmed that emotional intelligence has positive relationship with the nurses staff trust and Organization commitmentRecommendation: The nurses staff should be given periodically training to developing emotional intelligence skill which will increase level of trust and commitment.
\end{abstract}

\section{Keywords: Emotional intelligence, Organizational commitment \&Trust.}

\section{Introduction}

Individuals are more successful in their careers than others even when they have had equal educational and experiential opportunities (Mayer et al., 2018). Emotional intelligence People perceive this and use their thinking to manage their feeling Caruso et al .2016).

Emotional intelligence can assume a significant part in the working environment. The connection between emotional intelligence, work fulfillment and representative's presentation is predictable. emotional intelligence has been perceived as a powerful factor in both individual execution and authoritative execution and as a conceivably helpful idea in distinguishing factors in accounts of nursing practice that may be identified with improved maintenance of attendants and patient/customer results (Gorji et al, 2012).

Emotional intelligence can assume a significant part in the working environment. the connection between emotional intelligence, , work fulfillment and representative's presentation is predictable. emotional intelligence has been perceived as a powerful factor in both individual execution and authoritative execution and as a conceivably helpful idea in distinguishing factors in accounts of nursing practice that may be identified with improved maintenance of attendants and patient/customer results (Gorji et al, 2012).

Trust may characterized as an individual assumption or expectation about future activities that will be beneficial for their interest (EL-Sherbeny \& Rageb, 2019).

Emotional intelligence fosters trust and level of trust increased by increase level of emotional intelligence . A result of good initiative (which requires passionate intelligence)is trust. Fundamental exploration show that emotional intelligence and trust are related to each other. which has been shown in educational setting incorporate and manufacturing setting , and in one local public health setting .this research surveys the ideas of emotional intelligence and trust depending on a manager/staff member dyad in a state level legislative general wellbeing setting (Makkar,2019).

Emotional intelligence and trust affects success and confidence of employees, which leads to increased belonging to work and the performance of their duties and the high level of organizational commitment among individuals (Pitts J 2016).

This feeling of being dealt unfair and immense uncertainty may result in the action from the 
individual to reduce their attachment to the organization which in this term usually called as organization belonging (ELsaid, 2019).

\section{Significance of the study:}

The researcher as supervisor in directorate of health affairs noticed that the skills of emotional intelligence does not represent any importance to nurse managers in the selection or appointment of nursing staff and there is no understanding of the emotional intelligence and there is a permanent complaint of working conditions available and not to make any self-attempts to overcome obstacles to work without complaint or conspiracy.

Moreover the researcher noticed that there is a lack of communication between nursing staff and the nurse managers in different hospitals. Some nurses express a desire to leave hospital because they complaining from mistrust and unable to communicate with others Mohammed (2015) study the relation between emotional intelligence and work stress and effect on organization commitment and there was positive correlation between emotional intelligence and commitment.

Emotional Intelligence and trust seem to be positively influence to organizational commitment as studies Have Understanding the Role of Emotional insight and trust to the relation between Organizational Politics and Organizational Commitment (Antima et al.,2017) so ,its felt necessary to study relation between emotional intelligence and trust and how affect on organizational commitment.

Aims of the study:

This study aims to the effects of nurse's emotional intelligence and trust on Investigate organization commitment.

Specific objectives:

Assess the level of Emotional Intelligent, trust and commitment in three Hospitals.

Determination of the correlation between emotional intelligence and trust and the exclusion of the organizational commitment of the application sector.

Provide a set of recommendations and proposals for health officials based on the results of the research, which contributes to the development of this sector.

\section{Research questions:}

- Q1:What is the effect of emotional intelligence on organizational commitment?

- Q2: What is the effect of nurses trust on organizational commitment?

- Q3:What are the correlation between emotional intelligence and trust and their effect on organizational commitment in three hospital ?

\section{Subjects and methods}

Research design:

Descriptive correlational research design.

Sitting:

The study was conducted on three different health systems hospitals include. Main Assiut University hospital capacity (1244 )beds, Assuit General Hospital affiliated to Ministry of Health and Population. hospital capacity is (204)beds and Assiut Health Insurance Hospital , hospital capacity is(204)beds.

Subject:

A study subject consist of (575) nursing staff (nurse mangers and staff nurses) was determinate by using Thampson equation (2006) from three hospitals (main Assuit university, Assuit General and Assuit health insurance).By using this equation we will take $34 \%$ from total number of nursing staff.

$$
p\left(D_{\mathrm{O}}=d_{\mathrm{O}}\right)=\prod_{k=1}^{K}\left(\frac{1}{\left(\begin{array}{c}
N \\
n_{\mathrm{O} k}
\end{array}\right)} \prod_{t=0}^{n_{k}-n_{\mathrm{O}} k} q_{k, t, i}\right)
$$

Tools of the study:

Data was collected by using four tools:

- First tool: personal attributes as: Age , gender, unit, years of experience in the hospital, educational qualification and marital status.

- Second tool: Emotional intelligence questionnaire created by Salah, (2015) It used to asses nurses emotional intelligence, total items(28)It consists of(4) sub scale which include Self awareness(6items), self management (9items),Social awareness(5items), Manage Relation Ship(8items).

\section{Scoring system:}

Emotional intelligence questionnaire was measured 3 points scale ranging from "Agree" scored (3) to Disagree scored (1).

The third tool: Organizational commitment questionnaire developed by (Meyer, et al,2002). It consists (24) items distributed in three sub scales to measure affective, normative, and continuance organizational commitment.

\section{Scoring system:}

Organizational commitment questionnaire were measured using 5 points scale from "strongly agree" scored (5) to" strongly disagree" scored (1).

- The fourth tool: trust questionnaire: Include 12 item instrument, which was developed by (Cook and Wall,1980).

\section{Scoring system:}

Trust scale were measured using 5 points scale from "strongly agree" scored (5) to" strongly disagree" scored (1).

Validity of the instrument :

To ensure the face validity of the instrument, the questionnaire was assessed by 3 experts from 
teaching staff of Administration Sector Faculty of nursing. According to their recommendations, some questions were modified.

\section{Reliability of the study}

A pilot study was carried out on $10 \%$ of nurses. The sample for the pilot study was included within the study. Cronbach alpha was 0.807 . According to the feedback from the study participants, changes were made to some items.

\section{Reliability Statistics}

\begin{tabular}{|c|c|}
\hline Cronbach's Alpha & N of Items \\
\hline $\mathbf{0 . 8 7 3}$ & $\mathbf{6 4}$ \\
\hline
\end{tabular}

\section{Ethical considerations:}

Researcher take the approved to conduct this study from the dean of three hospitals participated in the study . Oral consent will be taken from nurses in study after explanation of the aim of the study .Participants ensured that the participation is voluntary, the data collected from each participant will treated with very security .

\section{Operational phase:}

These phases include two steps: pilot study and field work

\section{Pilot study:}

A pilot study was started after explain study tools to all nurses in march 2020to test the clarity and understandability of this tools, and determine problems that may be faced during data collection phase. It was applied to 10 nurses from the study sample. In pilot study data was collected and reviewed, not needed any modification then the final application of the study tools was started nurses participate at pilot study was excluded from the studied participants.

\section{Filed work:}

The actual data collected by the researcher from the nurses, From April 2020 to June 2020 by using the questionnaires. Data collected was administered by the researcher with each nurse separately in their work place in three hospitals.

A clarification of the aim of the study was given by the researcher to the participants. the questionnaire filled by every nurse took about thirteen min, the span of data collection was taking two months.

\section{Statistical design:}

Endless supply of data collection, data entry was done by using computer software package, statistically analysis was done by using spss 16.0statistical software package. Data were presented using descriptive statistics in quantitative variable, one-way variable test (ANOVA), statistical significance was considered at $\mathrm{p}<0.05$.

\section{Results}

Table (1): Distribution of the personal characteristics of the studied participants $(n=575)$

\begin{tabular}{|l|l|l|}
\hline Variable & No. (575) & \% \\
\hline Hospital: & \multicolumn{2}{|l|}{} \\
\hline Main Assiut University Hospital & 404 & $70.0 \%$ \\
\hline Health Insurance Hospital & 29 & $5.0 \%$ \\
\hline Assiut General Hospital & 142 & $24.7 \%$ \\
\hline Occupation: & \multicolumn{1}{|l|}{} \\
\hline Staff Nurse & 494 & $85.9 \%$ \\
\hline Nurse manager & 81 & $14.1 \%$ \\
\hline Age:(years) & \multicolumn{2}{|l|}{} \\
\hline$<30$ & 152 & $26.4 \%$ \\
\hline $30-40$ & 171 & $29.7 \%$ \\
\hline$>40$ & 252 & $43.8 \%$ \\
\hline Mean \pm SD (Range) & $37.62 \pm 9.69(21.0-54.0)$ & \\
\hline Sex: & \multicolumn{2}{|l|}{} \\
\hline Male & 118 & $20.5 \%$ \\
\hline Female & 457 & $79.5 \%$ \\
\hline Marital status: & \multicolumn{2}{|l|}{} \\
\hline Single & 156 & $27.1 \%$ \\
\hline Married & 404 & $70.3 \%$ \\
\hline Widowed & 10 & $1.7 \%$ \\
\hline Divorced & 5 & $0.9 \%$ \\
\hline
\end{tabular}




\begin{tabular}{|l|l|l|}
\hline Variable & No. (575) & \% \\
\hline Level of education: & & \\
\hline Secondary school of nursing & 410 & $71.3 \%$ \\
\hline Technical health institute & 80 & $13.9 \%$ \\
\hline Bachelor of nursing & 69 & $12.0 \%$ \\
\hline Master of nursing & 12 & $2.1 \%$ \\
\hline Doctorate of nursing & 4 & $0.7 \%$ \\
\hline Years of experience: & & \\
\hline$<10$ & 176 & $30.6 \%$ \\
\hline $10-15$ & 189 & $32.9 \%$ \\
\hline$>15$ & 210 & $36.5 \%$ \\
\hline
\end{tabular}

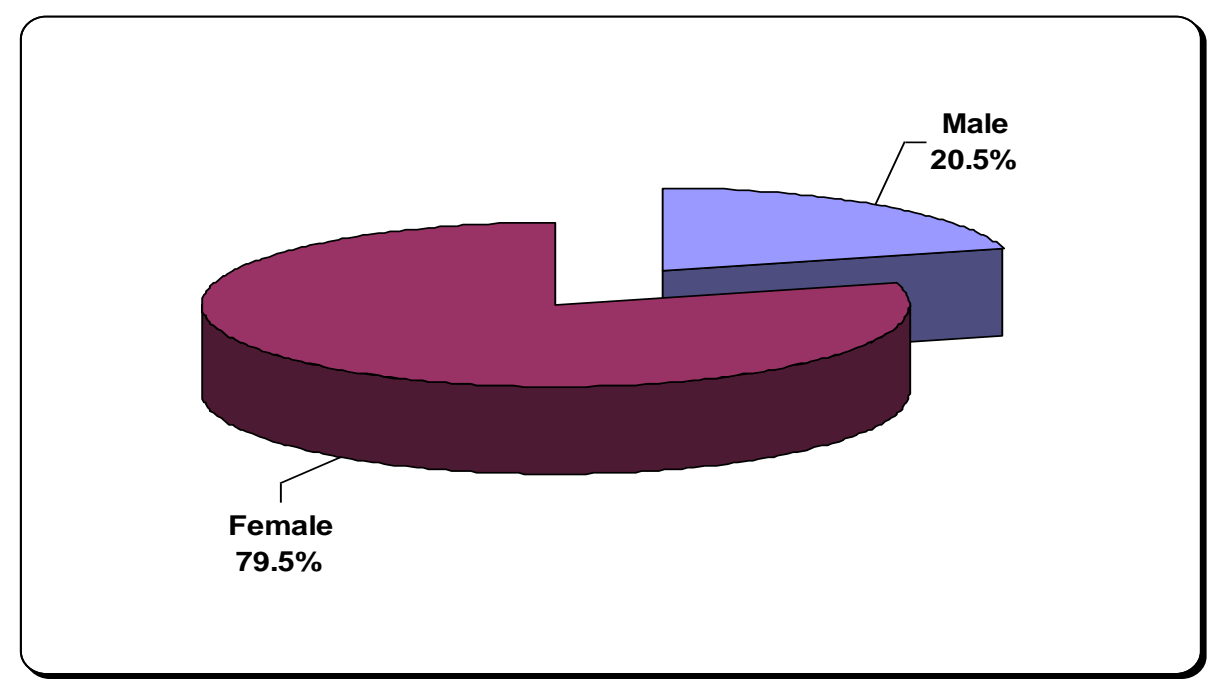

Fig (1): Distribution of the study participants according to sex.

Table (2) Distribution the levels of emotional intelligence, trust and organizational commitment according to study participants in three hospitals $(n=575)$

\begin{tabular}{|c|c|c|c|c|c|c|}
\hline \multirow{3}{*}{ Variables } & \multicolumn{6}{|c|}{ Hospitals } \\
\hline & \multicolumn{2}{|c|}{$\begin{array}{l}\text { Main } \quad \text { Assuit } \\
\text { University Hospital }\end{array}$} & \multicolumn{2}{|c|}{$\begin{array}{l}\text { Health Insurance } \\
\text { Hospital }\end{array}$} & \multicolumn{2}{|c|}{$\begin{array}{l}\text { Assuit General } \\
\text { Hospital }\end{array}$} \\
\hline & NO & $\%$ & NO & $\%$ & NO & $\%$ \\
\hline \multicolumn{7}{|c|}{ Emotional intelligence } \\
\hline low & 36 & 9 & 8 & 27.6 & 19 & 13.4 \\
\hline high & 369 & 91 & 21 & 72.4 & 123 & 86.6 \\
\hline \multicolumn{7}{|l|}{ Trust } \\
\hline low & 198 & 49 & 12 & 41.4 & 67 & 47.2 \\
\hline high & 206 & 51 & 17 & 58.6 & 75 & 52.8 \\
\hline \multicolumn{7}{|c|}{ Organizational commitment } \\
\hline Low & 71 & 28.7 & 15 & 51.7 & 35 & 24.6 \\
\hline High & 333 & 71.3 & 14 & 48.3 & 107 & 75.4 \\
\hline
\end{tabular}


Table (3): Correlation among trust score, emotional intelligence and organizational commitment among nurses participate in the study $(n=575)$

\begin{tabular}{|c|c|c|c|c|c|c|c|c|c|c|c|}
\hline Variables & & 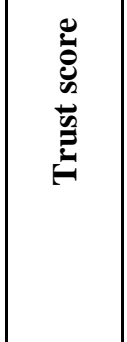 & 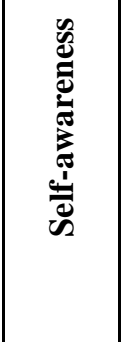 & 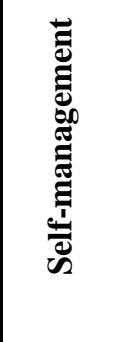 & 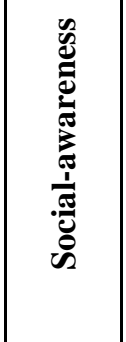 & 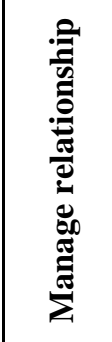 & 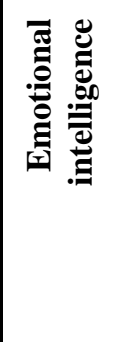 & 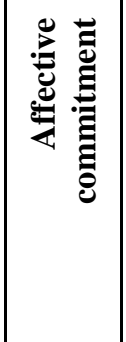 & 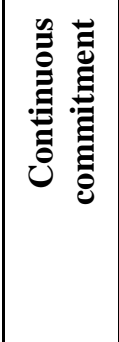 & 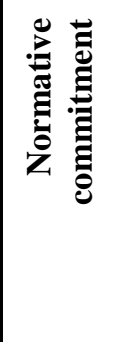 & 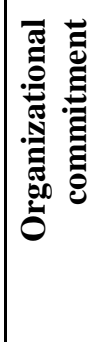 \\
\hline \multirow[t]{2}{*}{ Trust score } & $\mathrm{r}$-value & & & & & & & & & & \\
\hline & P-value & & & & & & & & & & \\
\hline \multirow[t]{2}{*}{ Self-awareness } & r-value & \begin{tabular}{|l|}
0.211 \\
\end{tabular} & & & & & & & & & \\
\hline & P-value & 0.000* & & & & & & & & & \\
\hline \multirow[t]{2}{*}{ Self-management } & r-value & 0.134 & 0.038 & & & & & & & & \\
\hline & P-value & 0.001* & 0.363 & & & & & & & & \\
\hline \multirow[t]{2}{*}{ Social-awareness } & r-value & \begin{tabular}{|l|}
$\mathbf{0 . 1 2 9}$ \\
\end{tabular} & \begin{tabular}{|l|l|}
0.141 \\
\end{tabular} & 0.016 & & & & & & & \\
\hline & P-value & 0.002* & 0.001* & 0.693 & & & & & & & \\
\hline \multirow{2}{*}{$\begin{array}{l}\text { Manage } \\
\text { relationship }\end{array}$} & r-value & \begin{tabular}{|l|l|} 
\\
\end{tabular} & \begin{tabular}{|l|l|}
0.214 \\
\end{tabular} & 0.033 & 0.504 & & & & & & \\
\hline & P-value & 0.004* & 0.000* & 0.425 & 0.000* & & & & & & \\
\hline \multirow{2}{*}{$\begin{array}{l}\text { Emotional } \\
\text { intelligence }\end{array}$} & r-value & \begin{tabular}{|l|}
0.225 \\
\end{tabular} & \begin{tabular}{|l|l|}
0.463 \\
\end{tabular} & 0.528 & 0.615 & $\begin{array}{l}0.756 \\
\end{array}$ & & & & & \\
\hline & P-value & 0.000* & 0.000* & 0.000* & 0.000* & 0.000* & & & & & \\
\hline \multirow{2}{*}{\begin{tabular}{|l}
$\begin{array}{l}\text { Affective } \\
\text { commitment }\end{array}$ \\
\end{tabular}} & r-value & \begin{tabular}{|l|}
0.193 \\
\end{tabular} & \begin{tabular}{|l|l|}
0.251 \\
\end{tabular} & 0.089 & \begin{tabular}{|l|}
0.067 \\
\end{tabular} & 0.084 & 0.182 & & & & \\
\hline & P-value & 0.000* & (0.000* & $0.033^{*}$ & 0.110 & 0.045* $^{*}$ & $0.000 *$ & & & & \\
\hline \multirow{2}{*}{$\begin{array}{l}\text { Continuous } \\
\text { commitment }\end{array}$} & r-value & \begin{tabular}{|l|l|}
0.226 \\
\end{tabular} & \begin{tabular}{|l|l|}
$\mathbf{0 . 1 7 8}$ \\
\end{tabular} & 0.071 & 0.068 & 0.076 & 0.138 & \begin{tabular}{|l|}
0.468 \\
\end{tabular} & & & \\
\hline & P-value & $0.000 *$ & 0.000* & 0.090 & 0.102 & 0.067 & 0.001* & 0.000* & & & \\
\hline \multirow{2}{*}{$\begin{array}{l}\begin{array}{l}\text { Normative } \\
\text { commitment }\end{array} \\
\end{array}$} & r-value & \begin{tabular}{|l|}
0.147 \\
\end{tabular} & 0.106 & 0.035 & 0.084 & 0.007 & 0.052 & 0.116 & 0.407 & & \\
\hline & P-value & 0.000* & 0.011* & 0.396 & $\mathbf{0 . 0 4 3}^{*}$ & \begin{tabular}{|l|}
0.861 \\
\end{tabular} & 0.217 & (0.005* & 0.000* & & \\
\hline \multirow{2}{*}{$\begin{array}{l}\text { Organizational } \\
\text { commitment }\end{array}$} & r-value & \begin{tabular}{|l|}
0.250 \\
\end{tabular} & \begin{tabular}{|l|l|}
$\mathbf{0 . 2 3 0}$ \\
\end{tabular} & 0.084 & \begin{tabular}{|l|}
0.099 \\
\end{tabular} & 0.070 & 0.157 & \begin{tabular}{|l|}
0.648 \\
\end{tabular} & \begin{tabular}{|l|}
0.834 \\
\end{tabular} & 0.741 & \\
\hline & P-value & 0.000* & 0.000* & 0.045* & $0.017 *$ & 0.095 & 0.000* & 0.000* & 0.000* & 0.000* & \\
\hline
\end{tabular}

Table (1): Illustrated that the high percent of the study subjects are females $(79,5 \%)$ and $(70,3 \%)$ were married, $(71,3 \%)$ of them had secondary nursing school and $(36,5 \%)$ of nurses had more than 15 years of experience.

Fig (1): Clears that the highest percent $(\mathbf{7 9 . 5 \% )}$ of the study participant female and the lowest percent $\mathbf{2 0 . 5 \% )}$ of the study participant from male.

Table (2): This table revealed that the majority of study participants in three hospitals (Main Assuit University, Health Insurance , Assuit General) reported a high level of emotional intelligence $(91 \%, 72.4 \%, 86.6 \%)$ with high level organization commitment in Main Assuit and Assuit General Hospitals $(71.3 \%, 75.4 \%)$ respectively and low level of commitment in Health Insurance Hospital (51.7\%), and high level of trust in three hospitals $(51 \%, 58.6 \%$ $, 52.8 \%)$.

Table (3): Shows There is a positive statistically significant correlations found between emotional intelligence and trust $(\mathrm{r}=0.225)$, While emotional intelligence had a week positive statistically significant correlation with organization commitment $(\mathrm{r}=0.157)$.

\section{Discussion}

Emotional intelligence is one of the biggest factors that contribute to the success of individual who assume various tasks and roles in modern life. It positively affects nurses and increase both trust and the ability to deal with stress (Kalyoncu et al., 2012).Emotional intelligence and trust affects the success and confidence of employees, which leads to increased belonging to work and the performance of their duties and the high level of organizational commitment among individuals (Pitts 2016).

Table (1): Shows that the most of the study subjects are females in three hospitals this might be attribute to the feminist nature of nursing profession, this result was consistent with Mohammed (2014)who illustrated that the gender different were not evident in the research, this may be due to the nature of the nursing profession, Nursing is known as a nurturing profession and the person attracted to this types of 
job, whether male or female, may possess this same quality.

As shown in (table , 2) more than three quarters of the study participants have high level of emotional intelligence in three hospitals, with high level of commitment, This might attribute to the study participant have high level of years of experience they have high level of communication that may improve their emotional intelligence, was supported with Jordan \& Troth (2012) who indicated that individual with high emotional intelligence prefer their work place with high level of conflict solution and organizational commitment .

The result of this study shown that the subject were had high level of trust this might be the hospital director are supportive them enough and they have high confidence in hospital administration. Laschinger (2013) are in congruent with the study result finding positive statistically significant correlations among trust and commitment.

Table (3) : The finding to this study illustrated that there are positive relations between emotional intelligence , trust and organizational commitment , this supported with Jordan \& Troth (2012)who indicated that individuals with high emotional intelligence prefer to committed to their work and seek to collaborative solution when facing conflict this increase level of trust.

\section{Conclusion}

The present study results concluded that there was high level of Emotional intelligence in three hospitals participated in the study this increase level of self confidence and high level of communication due to increase level of trust with high level of commitment.

\section{Recommendations}

- The Nurse staff member should be take periodic training for improving emotional competencies of nurses which will help them to manage their performance.

- Building a system for promotion at work according to achievement of standard commitment.

- This studies should determined the relationship between emotional intelligence, trust and organization commitment.

\section{References}

- Antima D, \& Qasim, S.H. (2017): A study of emotionalintelligence of secondary level student Review, 14, 47-65.

- Bar-On, R. (2015): The Bar-On model of emotional-social intelligence (ESI). Consortium for Research on Emotional Intelligence in Organizations. Retrieved from Consortium for
Research on Emotional Intelligence in Organizations website:

http://www.eiconsortium.org.

- Bishr, E., (2016): Emotional Intelligence And Its Relation To Academic Performance Among Alexandria University Dental Interns . Alexandria University .33' 49- 51.

- Cook, J, \& Wall, J, (1980): New work attitude measure of trust organization commitment and personal need no fulfillment, journal of occupational psychology, 53 -39 -52.

- Caruso, D., \& Bienne, B., (2016): Emotional intelligence in the workplace. In J. Ciarrochi, J. Forgas\& J. D. Mayer (Eds.), Emotional intelligence in everyday life (2nd ed.). Philadelphia: Psychology Press.

- El-sherbeny, A, (2019): Assessment Organizational Trust and Commitment among Nurses at Port Said Hospitals /31):65-72.

- El-saied, S., Ali, H., \& Adeyemo , D. (2019): Relationship between organization commitment, emotional intelligence and self - efficacy among faculty members in faculty of nursing Zagazig University , Egypt , Journal of Nursing Education and Practice , 4 (4), 183-193.

- Kalyoncu, Z, Guney, S \&Arslan, M (2012): Analysis of the relationship between Emotional Intelligance and trust Caused by Organization, Business IntelliganceJornal , 5(2),334-346 .

- Pitts J (2016): The effects of managerial communication and justice perceptions on employee commitment to organizational change: A mixed method field study: Alabama Auburn University.Retrievedfrom.http://hdli.handle.net/104 15/388.October ,10th2013.

- Lashchinger, H ., \& Finegan , J (2013): The impact of Workplace ,empowerment ,organizational trust on staff nurses work satisfaction and organizational commitment . Health Care Management Review.

- Meyer, J., Stanley, D., Herscovitch, L., \&Topolnytsky, L. (2002): Affective, Continuance, and Normative Commitment to the Organization: A Meta-analysis of Antecedents, Correlates, and Consequences. Journal of Vocational Behavior, 61(1), 20-52. doi:10.1006/jvbe.2001.1842.

- Meyer J., Stanley D., Herscovitch L., \& Topolnytsky L (2018): Affective, continuance, and normative commitment to the organization: A meta - analysis of antecedents, corr.elates, and of wor, empowerment, organizational trust. Journal of vocational behavior, 61(1), 20-52.

- Mohamed S (2018): the mediating effect of patient stratification on the patients perception of healthcare quality and patient trust, Vol 41, pp.574599. 
- Mohammed F (2014): Emotional intelligence and Conflict Management styles among Nurse managers at Assiut University Hospitals

- Makkar M (2019): The Impact of Emotional Intelligence on Managerial Employees Job Satisfaction. Ain Shams University pp.54-59.

- Salah, S (2015): The Effect of Emotional Intelligence in Achieving Organizational Commitment, Applied Study.

- Jordan J, \& Troth, C (2012): Emotional intelligence and conflict, resoluation in nursing. School of Management, Griffith University, Nathan, Queensland. 